\title{
Potentiating Death and Governing Uncertain Futures: Guns, Assisted Dying and the Production of Sovereign Subjects
}

\author{
Bradley Dunseith University of Toronto \\ Ari Gandsman University of Ottawa
}

\begin{abstract}
Both gun rights advocates and right-to-die activists shape their moral selves through time in relation to a demand of personal autonomy. Practising autonomy - having a sense of control over one's own life and death - becomes the principle of the good for both gun advocates and right-to-die activists. Though the ethical aims of both groups could not be more different, both movements produce a similar kind of subject. Whether through guns or end-of-life technologies, the person who has control over death has control over life, resulting in a subject actively working in and through time. However, while right-to-die activists take their own lives into their sovereign hands, gun owners engage with an ethics of time to prove their capacity in deciding who may live and who must die.
\end{abstract}

Keywords: gun rights, right to die, assisted dying, ethics, temporality, personal autonomy, sovereignty

Resumé : Les défenseurs du droit au port d'armes et les militants du droit de mourir construisent tous deux leur soi moral au fil du temps en fonction d'une exigence d'autonomie personnelle. Pratiquer l'autonomie - avoir le sentiment de contrôler sa vie et sa mort - devient le principe du bien à la fois pour les défenseurs du port d'armes et pour les militants du droit de mourir. Bien que les deux groupes aient des buts éthiques radicalement différents, ils produisent un type de sujet similaire. Que ce soit par le biais des armes à feu ou des technologies de fin de vie, la personne qui contrôle la mort contrôle la vie, ce qui donne lieu à un sujet qui travaille activement dans et à travers le temps. Or, si les militants du droit de mourir prennent leur propre vie entre leurs mains souveraines, les propriétaires d'armes à feu s'engagent dans une éthique du temps afin de démontrer leur capacité à décider qui peut vivre et qui doit mourir.

Mots clés : droits au port d'armes, possession d'armes à feu, droit de mourir, mort assistée, technologies de fin de vie, anthropologie de l'éthique, anthropologie du temps, autonomie personnelle, souveraineté, nécropolitique

394 / Bradley Dunseith and Ari Gandsman

\section{Introduction - Necropolitics and Individual Sovereignty: The Right to Die and the Right to Kill}

Bradley sits in a Taco Mac chain restaurant in Atlanta with Tony, a middle-aged IT professional who spends much of his free time buying, using and campaigning on behalf of guns. Tony usually "open carries" a handgun at his side when they meet. Today, he "conceal carries" his self-defence firearm because the restaurant has a large - albeit legally non-binding - sign at the front door prohibiting guns inside. Tony is one of many volunteer gun rights activists Bradley has met who helped make this sign unenforceable. He is part of a grassroots gun rights organisation in the state of Georgia that was instrumental in pushing through state legislation giving residents the right to carry firearms into a host of public areas including bars, restaurants, airport lobbies, certain places of worship and even some government buildings. Critics call it the "guns everywhere bill" ("Georgia 'Guns Everywhere' Law” 2014). "Anthropology?” Tony inquires, asking Bradley to explain how gun ownership falls into the purview of the discipline. Bradley responds by describing what anthropologists study, listing off the kinds of research projects friends and colleagues are currently engaged in, catching Tony's attention when mentioning right-to-die activism. "I'd march with those guys. I support euthanasia. What we are fighting for comes down to the same thing: personal autonomy."

On the other side of the world, in a trendy coffee shop in an upscale university neighbourhood of Sydney, Australia, Ari is speaking to a retired female social science professor who is on the board of a right-to-die organisation. She tells him, "When I think long and deep about my own interest in this subject, the two words that come to mind are not pain and suffering; they are autonomy and dignity and especially the autonomy thing." 
That the two make their demands using the same language is revealing, even if picturing gun rights advocates and right-to-die activists marching arm-inarm conjures up an odd image. The right to die largely emerges as a liberal, secularist critique of life-extending biomedicines with a rejection of an inherent sanctity of life while opponents are associated with the Catholic Church and Christian social conservatism. On the other hand, the gun rights movement is linked to right-wing Christian conservative politics (Melzers 2009). While gun rights groups in the United States want the state to acknowledge their rights and back off - perceiving government intervention (that is, restrictions on types of firearms, gun registries) as an infringement - right-todie activists want acknowledgement in order to provide individuals with assistance to die.

While the movements can be seen on separate sides of the political aisle, both demands are based on individual sovereignty over life and death on the right of personal autonomy and framed around a limited idea(l) of negative freedom. The two movements champion a dignity in life that can only be preserved through, alternately, a right to kill or a right to die in the context of a threat: in the former, a criminal or terrorist; in the latter, degenerative and/or terminal disease. In both cases, another external agent exerts unwarranted authority - a medical establishment oriented toward the preservation of life that robs patients of a choice in death versus a government attempting to curb a limitless right to bear arms by legislated control.

In this way, gun rights and right-to-die activism represent asymmetric manifestations of necropolitics, a politics of death. Mbembe $(2003,11)$ identifies this ultimate expression of sovereignty as "the power and capacity to dictate who may live and who may die." Necropolitics represents the flipside of Foucauldian biopolitics, a power organised around the maintenance and protection of life. Here, we see individual assertions of a demand for the power of death over life, exercised, alternately, on oneself or others. Both maintain the exercise of this sovereign capacity within a kind of individualised state of exception. For gun rights activists, it is the use of lethal force with the justification of the protection of life within the context of an imminent, potentially lethal threat (that is, a criminal or terrorist). For right-to-die activists, it is ending one's own life within a particular context of a legally defined set of conditions (that is, criteria such as terminal diseases with a prognosis of less than six months to live). In fact, what differentiates the right to die from suicide are particular "state of emergency" conditions that allow for it in the context of already imminent death.
As a result, gun rights activists push for fewer restrictions on firearm purchases, the opening of public spaces (restaurants, offices, theatres) to carrying guns, and legal protections for gun owners who use their firearms in self-defence through "castle doctrine" and "stand-your-ground" laws. ${ }^{1}$ In doing so, they assert a right to kill in the name of protection. Right-to-die activists, conversely, fight for sovereignty over their own lives by having the power and ability to choose the time of their death. Both groups ardently reject what they see as "bad deaths" that come from conditions of passive victimhood, whether stemming from crime or disease. In both cases, a gun or a lethal pharmaceutical are positioned as intervention and saviour. Although both can be linked to long-standing ideals, they are both expressions of modern concerns, products of biopolitical logic based on the promotion and preservation of life.

This article draws on ethnographic fieldwork among grassroots gun rights advocates in the US state of Georgia and right-to-die activists in Australia and Canada to understand how individual claims to sovereignty over life and death are predicated on largely ethical demands of personal autonomy and individual freedom. During and after both sets of fieldwork, as we discussed our work with one another, the importance of the role of necropolitics as a justification for the right to die or kill became increasingly clear. Based on two months of immersive participant observation with gun rights activists in the Metro Atlanta region and one year of research with right-to-die activists in Canada and Australia, this article examines what necropolitical power based on extreme interpretations of personal autonomy look like when comparing the right to end a life in both the assisted dying and gun rights movements.

As will be clear, this article does not draw a moral equivalence between these two movements but sets them up as diametrically opposed sides of the same necropolitical logic. Gun owners believe that their self-perceived responsibility and lack of criminal intent make their lives more sacred, thus making themselves worthier of life than an individual (often a thinly racialised "thug," "psychopath" or "terrorist") who would (or could) wilfully cause them harm. Gun owners grant themselves the right to reduce such a would-be perpetrator to a state of vulnerable bare life, who can be killed by virtue of their perceived immorality and potential for violence (Agamben 1998). Right-to-die activists, on the other hand, understand their own dying as "the counterpart and as another expression to live intensely" - acknowledging their own fragility and impermanence, which allows them to live more actively while alive by having the ability to die at any time 
(Braidotti 2013, 134). In the face of a shared recognition of the precarity of life, gun owners fortify their physical vulnerabilities against potential individual assailants, whereas right-to-die activists attempt to reckon with their vulnerabilities and the inevitability of death directly by controlling the moment that death takes place.

Both gun rights and right-to-die activists thus make claims in differing ways about what it means to live an ethical life. Recent anthropological work has highlighted the "centrality of ethical practice, judgement, reasoning, responsibility, cultivation, and questioning in social life" (Lambek 2010, 1) while moving beyond collective norms and obligations to understand the "practices and techniques that we perform on ourselves to become moral subjects" (Dave 2010, 372). In Infinitely Demanding, philosopher Simon Critchley $(2007,10)$ defines the moral subject as "the way in which a self binds itself to some conception of the good and shapes its subjectivity in relation to that good." Critchley argues that ethical experience can be understood as "the approval of a demand, a demand that demands approval" (16). Individuals require a certain degree of freedom to render themselves into ethical actors or to approve certain ethical demands while refusing others (Laidlaw 2014). Critchley's model of ethical experience is useful here as both gun rights advocates and right-to-die activists affirm demands of recognition of personal autonomy and press those demands onto the state. For example, in the case of the right to die, many point out that because suicide has been decriminalised, everyone in fact has a "right" to end one's own life. However, rightto-die activists differentiate suicide from a medically assisted death, which requires not only the involvement of medical personnel but also, unlike suicide, a positive approval of a demand. The right to die is a demand that demands approval.

Practising autonomy - having a sense of control over one's life and death - becomes the principal good for both gun advocates and right-to-die activists. Indeed, many right-to-die activists who procure end-of-life technologies do not actually use them, while gun owners who carry a firearm in their everyday lives rarely, if ever, draw their guns. For both groups, a morally good life is one where they can exercise control over their lives and deaths and refuse a "bad," "passive" or "victimised" death. By refusing to suffer passively (even if only in theory), right-to-die activists and gun advocates are rejecting the state's ability to determine appropriate degrees of risk or suffering their citizens may be subjected to (Das 1997). Both groups challenge norms and laws (carrying guns where they are not wanted, procuring end-of-life technologies) that they believe could potentially lead to suffering. In this way, they are refusing to see suffering or victimhood as a moral duty, challenging what Herzfeld (1992) calls a secular theodicy, in which the state takes the place of religion in explaining evil and appropriating suffering. The claims both groups make for personal autonomy constitute challenges to state sovereignty.

While the ethical aims of both groups could not be more different, both movements produce a similar kind of subject. Whether through guns or end-of-life technologies, the person who has control over death has control over life, resulting in a subject actively and calmly working in and through time. Since a threat could hypothetically materialise at any moment, both groups see the issue in terms of an emergency preparedness. Gun owners are constantly prepared to defend themselves, engaging temporally with the everyday in order to have the fastest response time to threats yet to exist. Rightto-die activists create their own temporal control of their lives with the ability to decide the exact moment they die, therefore hypothetically knowing the exact amount of time they have left to live. In both cases, this temporal control and awareness creates a sense of active calmness in the everyday. Right-to-die activists report that having access to the means of ending their lives helped with the "toxic anxiety" associated with the dying process; gun owners, meanwhile, frequently state that owning and carrying firearms provides them with a sense of peace. Jerry, a leading gun rights activist and public figure, explains that carrying a handgun alleviated his road rage. "When they wanna give you the finger and things like that," Jerry elaborates, "I just smile and say, you're lucky." Gun owners understand they have the power to kill another person because they are carrying a gun. This power over others' lives puts the pettiness of everyday disputes and drama into perspective.

In this article, we show how gun rights advocates and right-to-die activists shape their moral selfhood through time in relation to a demand of personal autonomy. In the first section, we look at how threats to personal autonomy are understood as unpredictable future potentialities that demand emergency preparation - whether that threat is a spontaneous burst of violence (for gun rights advocates) or the gradual effects of a degenerative illness (for right-to-die activists). What connects both gun owners and right-to-die activists in the politics of death is the attempt to control the uncontrollable, and this attempt is fundamentally a temporal activity. The second section deals with the ways in which 
both groups attune themselves to their unruly temporalities in an attempt to govern time. In the third section, we argue that these individuals are preparing themselves for the "right time": the exact moment in which they will exercise their sovereign power to die or to kill. This preparedness in time is not just an attempt to govern temporalities but to engage with time ethically, what Bear $(2016,494)$ calls phronesis: "The ethics of right action that contains accounts of what time is and what it should be used for." These activists and practitioners are trying to control the uncertainty of death by visualising it as something extremely specific, then controlling the specificities of those imagined circumstances. In doing so, these individuals are cultivating themselves into heroic subjects who refuse a passive death - and therefore a passive life. However, while right-to-die activists are taking their own lives into their sovereign hands, gun owners engage with the ethics of time to prove their capacity in deciding who may live and who must die.

\section{Configuring Time and Uncertain Futures}

Glen leans back in his chair and takes a sip from his iced tea. "When seconds count, the cops are only minutes away," he claims, repeating a well-worn slogan in many gun circles. "That is so true, I mean, four or five years ago we [in Cobb County, Georgia,] had the second fastest response time in the nation. You know what the time was? Two minutes and 58 seconds. Now think: There's somebody who's beating on your door. I mean they're trying to knock it down and you're on a 911 call." Glen invites Bradley to slowly count out 178 seconds aloud, imagining that an unknown assailant is working their way through his front door. "That's going to seem like a flipping eternity," he concludes.

The "threats" that lead many Americans to become gun owners are momentary, unexpected spurts of decontextualised violence that puncture the perceived safety and stability of the everyday. Gun owners imagine these threats as emerging without warning and being over in seconds; the only true defence to such a dangerously fast encounter is self-defence. While other Americans have taken up arms in response to professed police failure (Carlson 2012) or a more general sense of societal decline (Carlson 2015), the gun owners Bradley met are categorically clear that they carry firearms because no one else will be fast enough to help them, regardless of the efficacy of local police or alleged social (in)stability. As one gun rights advocate explains, even in an ideal environment or society, it is still important to carry a firearm because one can never control every single person: "In your perfect little world, everything's great and fine and dandy but there's the outside. That predator is going to come in whether you want him there or not. People come into your perfect little world and [you] have to stop them, you need to stop them." The future threats that gun rights advocates are preparing for and that guide much of their political work as activists are completely decontextualised from their everyday lives. Such threats are visualised as strangers battering down their front doors or breaking through a bedroom window, shooters opening fire in a theatre or mall. These potential threats are felt in time as sudden, instantaneous shocks. The emergence of such unruly temporalities can never be adequately predicted; they can only be generally prepared for.

The antithetical nature of these threats to the everyday lives of gun owners helps lay the foundation of a moral juxtaposition between threats as momentary events and the everyday lives of gun owners as linear, safe and good. These hypothetical moments are representations of possible futures that threaten, shape and justify gun owners' everyday routines and practices. Gun owners create a safe life for themselves by trying to govern the space and time around them, the "work of upholding certain temporal orders" (Ringel 2016, 393). Prioritising these highly unlikely futures is not a symptom of collective fear and paranoia for gun owners but a reference point in which they can attempt to control their own temporalities and shape their ethical selves. The constant anticipation of unruly and dangerous temporalities bound up in a potential moment of attack is a means by which gun owners further their understanding of what a good life means - a "mode of subjectivation" for fashioning themselves into ethical subjects (Faubion 2011, 3). Gun owners are attempting to uphold meaningful and legible temporal orders against an imagined violence that is senseless and random.

At a workshop sponsored by Dying With Dignity, Rodney Syme, a respected urologist and right-to-die activist who has openly defied Australian law by providing life-ending medication to dying patients, argues that everyone needs to be ready for their deaths and that death can come at any time, especially unexpectedly. "Dying well requires preparation," he tells the audience, as well as work. In an idealised form, dying well is an expression of living well, in which one's death and how one dies becomes a final statement of how one lives as an ethical subject. In an interview with Ari, Syme speaks of the death of his own father, another medical doctor, as an example of how the serenity and steadfastness with which he lived was matched by how he died. In his workshop, he provides information on what people can 
do where assisted dying is not yet recognised and goes through different options for different scenarios (for example, dementia and Parkinson's disease) that include the right to refuse medical interventions, the importance of advance directives and palliative care. He argues that it is difficult to make a rash decision during a crisis, so "thinking in advance" is required, especially within what is allowed "in [the] current legal circumstance." At the same time, he argues that "at the end you may be in the weakest position you've ever been in your life since you were babies."

The temporal dimension of waiting frames right-todie activism where medically assisted dying is available. Because numerous safeguards exist in which somebody has to make a request on two separate occasions with a gap of time (for example, ten days in Canada), waiting too long to make a request is not an uncommon experience. At the same time, individuals also often file a request, receive the prescription medication to end their lives, and do not end up using it. For example, in Oregon, 36 percent of individuals did not end up using their prescriptions (Blanke et al. 2017). This may be seen as evidence that they made the decision not to die by that means or, alternately, that their terminal condition had progressed beyond the point that would make self-administration possible.

Right-to-die activists push for the right to end one's life in order to save a patient from needless suffering and an agonising death. The future threat for right-to-die activists is neither human nor momentary, but a degenerative experience of time caused by physical illness in the context of certain death, which implies psychological suffering and anxiety caused by a passive state of waiting for the end of one's life. This suffering subject is perceived by right-to-die activists as gradually losing control over their own life, becoming dependent on others, growing weaker in the context of deteriorating physical and cognitive functions. Right-to-die activists argue that control over one's death allows them to regain control over the remainder of one's life (Hanning 2019). They are not attempting to uphold existing temporal orders; rather, they are attempting to sever the unravelling threads of a temporal breakdown with one clean cut.

Whereas gun owners perceive the uncertain future as a potential moment of senseless violence that needs to be stopped, right-to-die activists understand the future as something inevitable that must be confronted. Rightto-die activists do not have a collective reference point to build and juxtapose their ethical selves against - the kind of "bad guy" gun owners see looming in unruly future moments (Anderson 2017). No similar sense of "evil" exists in their world view; the "perpetrator" is an indifferent universe that gives rise to suffering and disease. Right-to-die activists have to reckon with their own impermanence; in an unfair present and uncertain future, individuals must confront their physical fragility and existential vulnerability. Anthropologists engaging with the ethical have highlighted the role of "fragility, precarity, vulnerability, and finitude" in moral experience (Mattingly and Throop 2018, 483). Gun rights advocates and right-to-die activists, in contrast, construct their notions of "the good" in relation to individual autonomy, which values moral certainty over "ethical precarity" (Mattingly 2018, 176). Both groups prioritise a personal autonomy that renders their own moral strivings more coherent and understandable in the face of a dangerous and uncertain world. However, while right-to-die activists treat this as a starting point, a "kind of quiet liberation" (Kleinman 2006, 10), gun rights activists consider it an end in itself - a normative mode of being in the world that simplifies the messiness of human life. "Making friends with the impersonal necessity of death," Braidotti $(2013,132)$ writes, "is an ethical way of installing oneself in life as a transient, slightly wounded visitor." Gun owners fortify their vulnerabilities and supplement their strength with firearms; right-to-die activists conversely come to terms with their own transient existences and work toward making the remainder of their time alive meaningful by exerting control over how and when they will die - thus making the future less uncertain.

At stake for both gun advocates and right-to-die activists is what they consider a bad death, to be avoided by all necessary means. Gun advocates understand a bad death as becoming a victim, where life is violently stolen in a sudden and senseless spurt of violence. Right-to-die activists view a bad death as a prolonged degeneration of one's self at the mercy of the medical establishment bent on prolonging life at all costs. Both hypothetical deaths, however, are imagined as passive, in which the person's life and death are now controlled by someone else, whether a violent stranger or a doctor. For both groups, heroism lies in refusing a bad death. Right-to-die activists wrestle a good death out of an impersonal illness and bureaucratic medical system, whereas gun advocates stand their ground against "bad guys." Right-to-die activists take control of the remainder of their lives by assuming the right to end their own lives; gun owners take control of their lives by assuming the right to end other peoples' lives.

\section{Governing Time}

Gun owners pre-empt dangerous future moments through everyday practices that strive to contain and limit other people. These everyday practices can be 
understood temporally as attunement and repetitions. Attunement here refers to the style in which individuals experience and co-produce temporalities, while repetitions are the everyday routines of gun owners enacted in time. These temporal movements in and of time impose and maintain a safe temporal order meant to keep gun owners out of danger and effectively "slow down" possible assailants. How gun owners carry their firearms in public demonstrates the ways in which they actively understand themselves as actors in time. In the state of Georgia, both "open carry" and "conceal carry" are legally viable options for gun owners. Some gun owners practise open carrying when in public (usually with a handgun holstered to their beltline), believing that it will deter would-be criminals. Other gun owners prefer to conceal carry (usually keeping a handgun at the beltline, underneath a loose-fitting, untucked shirt), assuming the element of surprise will provide them with additional crucial seconds to neutralise a threat. In general, gun owners believe that the sheer fact that civilians can carry guns restricts the possibilities of a threat emerging. Tony, who typically open carries one handgun while also conceal carrying another, argues that "being able to pull out a gun and shoot them - that makes them worried. That makes them think. That makes them slow down." Shooting someone, it should be noted, is also one of the fastest ways to stop a potential threat.

The problem of time for right-to-die activists who are planning their own death is locating a particular moment in time to end their lives. They are caught between a duelling logic of having to choose to die too early or risk waiting until it is too late (where the disease has progressed to the point that they can no longer self-administer death). In such a way, they speak of the potential of "having to leave a station early" in order to avoid "missing the bus." Such a calculation is often made in the context of a degenerative or terminal disease that has uncertain trajectories and prognoses that can vary dramatically from individual to individual.

\section{Attuning to Potential Futures}

Gun owners draw from a wide and diverse range of resources when trying to become "good" with a firearm. From training courses and workshops; to online and offline literature, forums and YouTube videos; to the mentorship of friends and family; to the tactical resources that teach gun owners how to shoot, often doubling as "moral resources," which instruct a gun owner on how to be a "good guy with a gun." Tactical prowess and moral strength become inseparable as gun owners actively reflect on who they are protecting by carrying a gun and what kinds of people they are readying themselves to shoot. Maintaining a heightened awareness of one's surroundings is an essential part of being a good gun owner, which joins skill and moral righteousness into one ethic. While some gun owners speak about such active attention colloquially ("keeping your head on a swivel"), most refer to it as "situational awareness" and can even cite a colour-coded level of increased awareness developed by former lieutenant colonel, shooting instructor and writer Jeff Cooper, which moves from white to yellow, orange and red (Fitzpatrick 2015). In this codified way of thinking about attention, most gun owners strive to maintain a yellow level of awareness, which means noting how many other people are in a room, where the exits are and whether anyone seems to be acting suspiciously or aggressively. In Tony's words, "code yellow" means keeping track of "what's in my environment so I can respond to it in case things start going bad." By actively monitoring their environment, gun owners attune themselves to the potential temporalities of public life, readying themselves for the right time in which they may have to act in self-defence. Cooper's colour-coded levels of awareness serve as both a tactical reference point as well as a moral resource that gun owners draw on to situate themselves as responsible gun owners in a potentially violent world.

Gun owners train their attention toward possible conflicts but move their bodies away from the first signs of a conflict's enactment. Sheryl, a shooting instructor for women and an active gun rights activist, explains that learning to be aware of one's surroundings means first avoiding an incident and only fighting back when necessary. She emphasises that the first sign of trouble is enough to warrant extreme avoidance. "Say we're in a restaurant like this one," she says over barbequed chicken wings and French fries at a small roadside diner, "and there's people back over in the corner raising their voice, getting really loud and boisterous with each other. Check please, I'm out the door." Sheryl's active avoidance of possible threats is echoed by a workshop conducted by the National Rifle Association (NRA) called Refuse to Be a Victim.

During the session Bradley attends in Marietta, Georgia, the two presenters devote a large section of the workshop to delivering a long list of things people generally should not do. This includes picking up hitchhikers, opening the front door of your house to strangers (even a mailman), giving directions when asked on the street, and attending large events like rock concerts. The presenters' long list of edicts amounts to asking the audience to avoid strangers at all costs. Gun owners draw on and individualise these diverse moral 
resources when fashioning themselves as ethical actors. Veena Das argues that the everyday constitutes a "site in which the life of the other is engaged" $(2010,376)$ and that to "create a space for the other is itself a mode of living ethically" (2015, 75). Gun owners, however, work on themselves as ethical actors by maintaining distance between themselves and the other, using the everyday as a spatial and temporal site to constantly monitor human spontaneity and control the unpredictability linked to human agency or freedom. By studiously avoiding quotidian confrontations and hostilities, gun owners assume both the ability and the right to determine which situations transcend the everyday and merit lethal intervention.

Similarly, right-to-die activists discuss with others on member forums or in meetings (such as the coffee-andchat group discussions Ari attended) about how to know when to find the right time and how to use the right methods to die. One coordinator stated, "You'll know when the time is right," but a woman with two late-stage cancers is doubtful of this, in particular because she sees herself as a fighter with an indomitable spirit to live. In her case, the risk is having a "bad" and long-drawn-out death, one that she witnessed repeatedly in her years as a hospital nurse. Having secured the pharmaceutical means to end her life, on the other hand, she feels free by having this form of responsibility and is able to feel better prepared to locate herself in time by having the means at her disposal to deliver herself from it - "an exit," as she called it.

\section{Rituals of Preparedness}

Practices of avoidance are meant to control the unexpected, keeping gun owners away from unruly temporalities. When such unruly times are unavoidable, using a firearm becomes the final means of governing uncertain futures. Gun owners spend hours repeating the same physical motions of drawing their firearms to shave down seconds in their response time to hypothetical threats. Whether repeatedly unholstering a gun from their beltline in the mirror or practising the act of drawing a firearm from a hidden location in their homes, gun owners are honing their ability to stop a quick, sudden threat. For that reason, most gun owners also have the safety mechanism of their firearms switched off and keep a bullet chambered in their gun so they do not have to cock the firearm - saving a few (hypothetical) life-saving seconds. Allen, a restaurant manager who has written permission to carry a concealed handgun at work, says that he keeps a handgun in between his couch cushions and another strapped to the leg of his bed. "It doesn't make sense to be sitting there when somebody breaks in and I have to walk upstairs to my gun safe," he argues emphasising that a threat would arise so quickly and sporadically that not being ready at a moment's notice could be fatal.

Similarly, in workshops by radical right-to-die organisations, members learn how to prepare for their own deaths and can choose the most "peaceful" and "reliable" means of dying. The workshops become a kind of ritualised preparedness for dying as attendees learn which pharmaceuticals work best and how to obtain them through illicit means. They also learn of using nitrogen tanks and other forms that they can then store at home; and in interviews, they speak of how they "practise" their deaths. Thinking about, planning and preparing for their deaths in such a way is seen by right-to-die activists as a way of preparing for uncertainty and having a small degree of control over processes that they would otherwise have no control over. According to radical right-to-die activists who embrace a do-it-yourself approach, procuring an end-of-life method, like importing the illegal pharmaceutical Nembutal (a sodium pentobarbital that one can illegally import from veterinary providers in Mexico or order online from China), even among people who are not sick, is to have consciously and deliberately made an active assertion of agency while also consciously calculating when the right time might be. A rhetoric of emergency preparedness is common, but procuring one's means of death also comes with a feeling of liberation and relief. This is especially true of those whose right-to-die activism was sparked by having witnessed the suffering and drawn-out deaths of loved ones. Just like the gun activist who stashes a handgun in between his couch cushions, having Nembutal stashed away in the cupboard "just in case" or "because you never know when you may need it" is the way rightto-die activists fashion themselves into ethical subjects who, once in possession of the means to end one's life, can then deliberate when and, if that time may come, when they may use it.

In her review of the anthropology of time, Munn $(1992,102)$ notes that repetition "is inextricable from the nonrepetitive growth it produces." The repetitive actions of drawing a holstered or concealed gun in anticipation of a self-defence moment creates not just what gun owners often refer to as muscle memory but a belief that their safety is threatened by dangerous temporalities that need to be forcefully slowed down. These repetitions help construct a way for gun owners to tell time, which Munn calls "time-reckoning": contingent events that ask when something will or should happen that is "operationalized by formulating a conjunction or synchronization between the reference point and the event to be located" 
(102-103). Because a future threat does not have a measurable duration, its occurrence is experienced as constantly imminent, yet never tangibly approaching. Gun owners try to control the time around them, constructing a temporal fortress to protect themselves if and when these threats do come.

Similar to gun rights advocates, threats to life for right-to-die activists have a similar intangible immanence. Degenerative diseases do not work on a clear schedule, forcing individuals to prepare for the possibility of a sudden change in health - while at the same time leaving the possibility open that they may try ending their lives prematurely. In both cases, the ritual of preparation offer a sense of control over the uncertain future irrespective of whether the individuals use their means of dying or killing.

However, while gun rights advocates are largely grappling with hypothetical scenarios, those seeking end-of-life technologies are actually dying. Right-to-die activists are attuning themselves to and preparing for the bodily vulnerability that has already been exposed and marked. Gun rights advocates, on the other hand, are attuning themselves to potential futures marked by unlikely violence, effectively denying their vulnerability to the other through what Judith Butler (2004, 29) calls a "fantasy of mastery." Gun owners refuse the "vulnerability to a sudden address from elsewhere" (149) inherent in human relations by imagining themselves as constantly prepared for the slightest human provocation. Butler writes that "tragically, it seems the U.S. seeks to pre-empt violence against itself by waging violence first, but the violence it fears is the violence it engenders" (149). Gun owners are not waging war; however, the rituals of preparation they engage in risk turning a slight altercation into a lethal intervention: engendering the violence they are preparing themselves against.

\section{The Right Time: Sovereignty and Phronesis}

It is nearing midnight as Bradley stands in a now-deserted parking lot with Tony. "If a man was running towards you from over there," Tony says, pointing to the highway, "and he was armed and yelling that he was going to kill you, would you not draw a weapon and defend your own life?" Throughout Bradley's fieldwork in Georgia, gun owners regularly framed ethical questions of gun ownership and self-defence in urgent ultimatums: defend oneself or become a victim; kill or be killed.

Bradley, gazing out at the empty highway, is uncomfortable at having to answer such a morally demanding question, which clearly has only one culturally correct answer. "Honestly," he tells Tony after an awkward pause, "I don't think I could murder someone." Tony, exasperated, responds, "There is a fundamental difference between murder and killing. And if you don't understand that, you haven't understood anything I've been talking about this whole time." Tony asks if Bradley's life is not "worth more" than the life of someone who was willing to kill him without provocation. "You have a moral responsibility," Tony concludes before calling it a night and driving Bradley back to the motel he has been staying at in Kennesaw, Georgia, "to yourself and to those you care about to protect yourself."

Right-to-die activists, on the other hand, do not refer to ending their life as a moral responsibility. They differentiate between having the means to end their lives and actually using them. They do not see it as a failure for someone to have procured life-ending medication and then ending up dying from the disease that they were suffering from. Having the material means to end one's life is seen to be comforting enough. The substance itself, however, represents both a way of preparing for future moments and an ethical way of dealing with the dying process through time - of entering a liminal state in which death is imminent.

By repeatedly preparing for a potential future moment while actively attempting to avoid unnecessary conflict, gun owners construct a moral framework for evaluating a potentially dangerous situation that legitimises their own violent intervention. Phronesis, or acting ethically at the right time, is treated as the ultimate heroic action, the hypothetical situation of self-defence that gun owners are constantly preparing for. "It comes down to courage," Dan, a prominent gun rights activist and retired platoon officer argues. "Are you willing to fight back? You need to make that decision maybe in seconds." A gun owner must be in control to react effectively against the immediate emergence of a threat, while retaining the ability to determine when a threat merits retaliatory force.

This moral framework, however, can be self-serving. By emphasising the importance of being ready for the "right time," gun owners are claiming sovereignty over others' lives. Through practices of avoidance and attunement, gun owners prepare themselves to act in self-defence if the moment comes. But what this moment looks like and what an appropriate response could look like are decided by gun owners - an important point when other people's lives are potentially on the line. The act of repetitive practices in relation to unknown future threats serves as cultural proof of a gun owner's ability to identify potential threats and, therefore, their right to lethally intervene in them. 
Organisations like the NRA offer additional moral instruction and validation to gun owners' power over others' lives and deaths. Writing on her own experience at an NRA training workshop, sociologist Jennifer Carlson describes much of the course content as providing gun owners with the moral logic to justify killing someone else. Carlson $(2015,76)$ writes that the narrative of the workshops focuses on the inherent immorality of "bad guys" and "individualizes the problem of crime and moves killing - in some circumstances - from an immoral act to a moral act. It spells out who is worthy and unworthy of life." This sovereign right is further legitimated by self-defence laws legislatively adopted by many American states that legally permit individuals to use deadly force when they have reasonable belief that their life is in danger. The professed ability to identify when one's life is in alleged danger becomes in itself one of the legal and moral proofs of a gun owner's sovereign right to kill a would-be assailant. Gun owners solidify their sovereign power by restraining themselves when the time is not right to use lethal force. They readily acknowledge this responsibility, as Jerry explains: "You've got something on your hip that can end somebody's life." The gun owners Bradley met are also meticulously careful with firearms. Despite keeping a bullet chambered in a gun, for instance, they never keep their finger near the trigger unless they are going to shoot. Even unloaded firearms are always, without exception, pointed at the ground when being handled. Knowing how to safely handle firearms and when to use them is understood by gun owners as a responsibility. It is by cultivating this sense of responsibility with guns (how to be safe with them, when not to use them) that gun owners legitimate their sovereign power over other lives.

Most gun owners further believe that if they are presented with a situation in which they have to use their firearm in self-defence, it is important to shoot to kill. Gun owners want to stop a threat, and some express concern that there is no certainty the threat will be completely stopped if the hypothetical attacker is still alive. Other gun owners, however, are more candid in stating that in shooting to harm and not kill, gun owners are leaving themselves exposed to a new kind of legal threat. "If you pull your gun out you better be ready to kill," Allen explains: "Because it's either their life or your life at this point. If you shoot them in the knee, then there's another person there that might have a different story." Another gun owner admits that if someone mugged him, he would probably shoot to kill the person who violated his personal autonomy. Gun owners are explicit that someone who actively puts their own life in danger no longer deserves to live. "He comes and tries to murder me?" Tony says, imagining a hypothetical, violent stranger. "Fuck him. He does not deserve my air. If you break the social contract - the most basic level of agreement: I don't kill you, you don't kill me. If you break that you don't deserve any more consideration. You're off the list." Because an individual is read by their temporality, gun owners claim a wide array of actions that justify lethal force. Because threats are imagined as sporadic and unpredictable, hostile - though not necessarily life-threatening - acts can morally and legally justify lethal intervention.

Late one evening in downtown Atlanta, Bradley walks home with Patrick, a young gun rights activist, after a night of drinking. A seemingly inebriated man swinging what looks like a tire iron approaches them and asks for spare change. Bradley hands the man a dollar bill; he thanks them both and continues walking in the opposite direction. Once they cross the street, Patrick turns to him: "You may have saved that man's life."

\section{Killing and Dying: The Final Moment}

While writing an early draft of this manuscript, Bradley steps out of his apartment to run some errands when a stranger runs up behind him and forcefully strikes the back of his head with his open hand. Bradley turns around in shock. The man yells at him for half a minute and raises his arm as if to strike again before crossing the street and disappearing onto a city bus. Terrified and in a small amount of pain, Bradley is still able to enjoy to irony of the situation. He spent the morning writing about how gun owners spend their everyday lives preparing for a very narrowly defined, highly unlikely threat to emerge. In the afternoon, such a threat - anonymous, unexpected, instantaneous - descends upon him. Bradley remembers one of Tony's statements: “There's people who do not carry [a gun] and are willing to expose themselves to this threat and they're willing to die, saying, 'I won this time, I won this time, I won this time. Look at how often I won.' I look at it and say, yeah but there's a time when you're not going to win."

Bradley is left with a small headache and an unsettled feeling, but nothing more: the man is gone. Did this stranger deserve death for a bizarre and admittedly minor assault? Gun owners' constant preparation for the emergence of unruly temporalities reconstructs what would otherwise be a crime, or an unpleasant situation, into a life-or-death moment.

While doing fieldwork, Bradley met a gun advocate named Nick who had killed in self-defence. Nick was ambushed by two men while returning to his car after spending the evening at a friend's house. One man put 
a paring knife to his neck and the other demanded his car keys and wallet. Nick pushed the man with the paring knife away, unholstered his concealed handgun and killed him. "I don't regret any of my decisions," Nick tells Bradley. "I didn't want to be in that situation in the first place but since it happened, I think I handled it fairly well." Carlson $(2015,2)$ recounts a similar incident during her research among gun owners in Michigan when a store clerk fatally shot a young man attempting to rob the store with what turned out to be a toy gun. "It doesn't bother me," he told Carlson. Gun owners categorically refuse the messiness and danger of human life; they are willing to kill to protect their own lives. Right-to-die activists, on the other hand, embrace the precarity of their own lives and do not set themselves apart from others. Death may lurk in the background of life and can interrupt it at any time. Terminal disease may strike at any moment, in the same way as a mass shooting, criminal mugging or terrorist attack. While the former allows one to meditate on life's precarity in order to embrace it, the other recognises it in order to deny it.

Constantly preparing oneself for these unruly moments of time moves a number of transgressions (such as robbery, assault) into killable offences and may even precipitate a shooting. Threats conceptualised as random, anonymous spurts of violence also obscure two major kinds of gun-related violence: domestic violence and suicide. Between 2010 and 2017, gun-related murders of intimate partners rose by 26 percent in the United States. In 2017, 926 women were fatally shot by their intimate partners (Fridel and Fox 2019). Suicide consistently accounts for the highest number of gun deaths in the United States. Out of the total 38,658 firearm-related deaths in 2016, 22,938 were suicides (Xu et al. 2018).

The imagery used to describe unruly temporalities is often racially coded, placing people of colour, especially African American men, at a heightened risk of being wrongly perceived as a threat and therefore killed. In her book Loaded: A Disarming History of the Second Amendment, historian Roxanne Dunbar-Ortiz $(2018,57)$ situates contemporary American gun culture within the histories of settler colonialism and white nationalism, writing that the Second Amendment was "intended as a means for white people to eliminate Indigenous communities in order to take their land, and for slave patrols to control Black people." There are parallels in how contemporary gun owners imagine hypothetical assailants and how early settlers characterised Indigenous populations as "inherently disposed to cruel and atrocious violence” (42-43). Similarly, gun owners' concern with an instantaneous, anonymous and seemingly out-of-nowhere threat resonates with early settler concerns with Indigenous resistance where Indigenous fighters attacked "the settlers' isolated farms, using a method that relied on speed and caution in striking and retreating, and possessing of course a perfect knowledge of the terrain and climate" (44). The kind of specific threats gun owners prepare for (and make themselves ethically good in relation to) echo colonial settler anxieties of securing conquered land from its original inhabitants.

Preparing for an unexpected violent threat may reflect historic colonial anxieties; however, this preparation is not anxiety-inducing for contemporary gun owners and advocates. Both gun advocates and right-to-die activists claim sovereignty over life and death to have the freedom to become moral subjects, "to achieve happiness, brilliance, and life" (Dave 2010, 372). But the contrasting moments in which this sovereignty is exercised are at radical odds with each other. For right-to-die activists, the moment of sovereignty occurs as a suffering patient wilfully puts an end to their own life within the circumstances they feel provide closure to their life. For gun advocates, someone else's life is violently taken away. If, as Veena Das $(2015,75)$ writes, "to create a space for the other is itself a mode of living ethically," what kind of ethical life is predicated on an armed denial of that space to the other?

The anthropological literature on ethics and morality aims to recognise ethics as a part of the human condition, which "happens in practice rather than knowledge, recognizes human finitude but also hope" (Lambek 2010, 2), while Fassin (2008) argues that a moral anthropology should not degenerate into a moralising project. In this article, we have attempted to demonstrate how the kind of ethical work gun advocates perform on themselves to make them "good guys with guns" also helps morally justify their ability to decide who lives and who dies, propelling a politics of exclusion and denial of the other. The ethical vision of gun owners simplifies the world into good and bad and denies individuals their complexity at the risk of the gun owner's own physical vulnerability. The good guy with the gun is an ethical, sovereign subject fashioned at the expense of other lives; woven into the subject position is the explicit agreement that certain lives are expendable. Both the right-to-die and gun rights movements make a claim to sovereignty based on the absolute right of personal autonomy. The personal autonomy of gun advocates, unlike that of right-to-die activists, is also a claim that their own autonomy is more important than the autonomy, security and safety of others. 
Bradley Dunseith, Department of Anthropology, University of Toronto, Toronto, Ontario, Canada. Email: bradley.dunseith@mail.utoronto.ca.

Ari Gandsman, Department of Sociology and Anthropology, University of Ottawa, Ottawa, Ontario, Canada.Email: ari.gandsman@uottawa.ca.

\section{Acknowledgements}

This research was funded by grants from the Social Science and Humanities Research Council. We would like to thank our two reviewers for their constructive input.

\section{Note}

1 Stand-your-ground laws grant individuals the right to use "justifiable" force when they have "reasonable" belief that their life is in danger. Castle doctrine grants immunity to an individual who acts in self-defence within his or her own home or vehicle against a trespasser. At the time of writing, 28 U.S. states had a version of stand-your-ground laws (including Georgia) while 11 states had only castle doctrine.

\section{References}

Agamben, Giorgio. 1998. Homo Sacer: Sovereign Power and Bare Life, translated by Daniel Heller-Roazen. Stanford, CA: Stanford University Press.

Anderson, Joe. 2017. "Gun Owners, Ethics, and the Problem of Evil: A Response to the Las Vegas Shooting." HAU: Journal of Ethnographic Theory 7 (3): 39-48. https://doi. org/10.14318/hau7.3.003.

Bear, Laura. 2016. “Time as Technique.” Annual Review of Anthropology 45: 487-502. https://doi.org/10.1146/ annurev-anthro-102313-030159.

Blanke, Charles, Michael LeBlanc, Dawn Hershman, Lee Ellis and Frank Meyskens. 2017. "Characterizing 18 Years of the Death with Dignity Act in Oregon.” JAMA Oncology 3 (10): 1403-1406. https://doi.org/10.1001/ jamaoncol.2017.0243.

Braidotti, Rosi. 2013. The Posthuman. Cambridge: Polity Press.

Butler, Judith. 2004. Precarious Life: The Powers of Mourning and Violence. New York: Verso.

Carlson, Jennifer. 2012. “'I Don't Dial 911': American Gun Politics and the Problem of Policing." British Journal of Criminology 52: 1113-1132. https://doi.org/10.1093/bjc/ azs039.

- 2015. Citizen Protectors: The Everyday Politics of Guns in an Age of Decline. New York: Oxford University Press.

Critchley, Simon. 2007. Infinitely Demanding: Ethics of Commitment, Politics of Resistance. New York: Verso.

Das, Veena. 1997. "Sufferings, Theodicies, Disciplinary Practices, Appropriations." International Social Science Journal 49 (154): 563-572. https://doi. org/10.1111/j.1468-2451.1997.tb00045.x.
. 2010. "Engaging the Life of the Other: Love and Everyday Life.” In Ordinary Ethics: Anthropology, Language, and Action, edited by Michael Lambek, 376399. New York: Fordham University Press.

. 2015. "What Does Ordinary Ethics Look Like?" In Four Lectures on Ethics: Anthropological Perspectives, edited by Michael Lambek, Veena Das, Didier Fassin and Webb Keane, 53-125. Chicago: HAU Books.

Dave, Naisargi. 2010. "Between Queer Ethics and Sexual Morality.” In Ordinary Ethics: Anthropology, Language, and Action, edited by Michael Lambek, 368-375. New York: Fordham University Press.

Dunbar-Ortiz, Roxanne. 2018. Loaded: A Disarming History of the Second Amendment. San Francisco: City Light Books.

Fassin, Didier. 2008. "Beyond Good and Evil? Questioning the Anthropological Discomfort with Morals." Anthropological Theory 8 (4): 333-346. https://doi. org/10.1177/1463499608096642.

Faubion, James D. 2011. An Anthropology of Ethics. New York: Cambridge University Press.

Fitzpatrick, Brad. 2015. "Col. Jeff Cooper: Developing a Defensive Mindset.” Guns\&Ammo, 17 August. https:// www.gunsandammo.com/editorial/col-jeff-cooperdeveloping-a-defensive-mindset/249086 (accessed 20 February 2020).

Fridel, Emma E., and James Alan Fox. 2019. "Gender Differences in Patterns and Trends in U.S. Homicide, 1976-2017." Violence and Gender 6 (1): 27-36. https://doi. org/10.1089/vio.2019.0005.

“Georgia 'Guns Everywhere' Law Takes Effect.” 2014. Al Jazeera America, 1 July. http://america.aljazeera.com/ articles/2014/7/1/georgia-guns-everywhere.html (accessed 20 February 2020).

Hanning, Anita. 2019. "Author(iz)ing Death: Medical Aid-inDying and the Morality of Suicide." Cultural Anthropology 34 (1): 53-77. https://doi.org/10.14506/ca34.1.08.

Herzfeld, Michael. 1992. The Social Production of Indifference: Exploring the Symbolic Roots of Western Bureaucracy. Chicago: University of Chicago Press.

Kleinman, Arthur. 2006. What Really Matters: Living a Moral Life amidst Uncertainty and Danger. Oxford: Oxford University Press.

Laidlaw, James. 2014. The Subject of Virtue: An Anthropology of Ethics and Freedom. Cambridge: Cambridge University Press.

Lambek, Michael. 2010. "Introduction.” In Ordinary Ethics: Anthropology, Language, and Action, edited by Michael Lambek, 1-36. New York: Fordham University Press.

Mattingly, Cheryl. 2018. "Ordinary Possibility, Transcendent Immanence, and Responsive Ethics: A Philosophical Anthropology of the Small Event." HAU: Journal of Ethnographic Theory 8 (1/2): 172-184. https://doi. org/10.1086/698269.

Mattingly, Cheryl, and Jason Throop. 2018. "The Anthropology of Ethics and Morality." Annual Review of Anthropology 47: 475-492. https://doi.org/10.1146/ annurev-anthro-102317-050129.

Mbembe, Achille. 2003. "Necropolitics." Public Culture 15 (1): 11-40. https://doi.org/10.1215/08992363-15-1-11. 
Melzers, Scott. 2012. Gun Crusaders: The NRA's Culture War. New York: New York University Press.

Munn, Nancy D. 1992. "The Cultural Anthropology of Time: A Critical Essay." Annual Review of Anthropology 21: 93-123. https://doi.org/10.1146/annurev.an.21.100192. 000521.

Ringel, Felix. 2016. "Beyond Temporality: Notes on the Anthropology of Time from a Shrinking Field Site."
Anthropological Theory 16 (4): 390-412. https://doi. org/10.1177/1463499616659971.

Xu, Jiaquan, Sherry Murphy, Kenneth Kochanek, Brigham Bastian, and Elizabeth Arias. 2018. "Deaths: Final Data for 2016." National Vital Statistics Report 67 (5): 1-76. 